\title{
CSF3 wt Allele
}

National Cancer Institute

\section{Source}

National Cancer Institute. CSF3 wt Allele. NCI Thesaurus. Code C49781.

Human CSF3 wild-type allele is located within $17 q 11.2-q 12$ and is approximately $2 \mathrm{~kb}$ in length. This allele, which encodes granulocyte colony-stimulating factor protein, is involved the production, differentiation, and function of granulocytes. 